\title{
Redescription of the net-casting spider Asianopis goalparaensis (Tikader et Malhotra, 1978) comb.n. (Araneae: Deinopidae) from India
}

\section{Переописание паука-деинопиды Asianopis goalparaensis (Tikader et Malhotra, 1978) comb.n. (Araneae: Deinopidae) из Индии}

\section{Paris Basumatary ${ }^{1}$, John T.D. Caleb ${ }^{2, *}$, Sangeeta Das ${ }^{3}$, Dulur Brahma ${ }^{1}$ Парис Басуматари ${ }^{1}$, Ажкон T.А. Камеб ${ }^{2, *}$, Сангита Аас ${ }^{3}$, Аулур Брахма ${ }^{1}$}

\author{
${ }^{1}$ Department of Zoology, Bodoland University, Assam - 783370, India. \\ 2 Zoological Survey of India, Prani Vigyan Bhavan, M-Block, New Alipore, Kolkata - 700053, West Bengal, India; email: \\ caleb87woodgate@gmail.com \\ ${ }^{3}$ Department of Zoology, Assam Don Bosco University, Assam - 782402, India. \\ *Corresponding author
}

KEY WORDS: Aranei, Assam, diagnosis, Kokrajhar, morphology, taxonomy.

КЛЮЧЕВЫЕ СЛОВА: Aranei, Ассам, диагноз, Кокражхар, морфология, таксономия.

ABSTRACT: Asianopis goalparaensis (Tikader et Malhotra, 1978) comb.n. belonging to the liukuensis species group is redescribed on the basis of fresh specimens collected from Assam, India. Detailed illustrations, a distributional map and notes on its natural history are provided.

How to cite this article: Basumatary P., Caleb J.T.D., Das S., Brahma D. 2020. Redescription of the netcasting spider Asianopis goalparaensis (Tikader et Malhotra, 1978) comb.n. (Araneae: Deinopidae) from India // Arthropoda Selecta. Vol.29. No.3. P.325-329. doi: 10.15298/arthsel. 29.3.04

РЕЗЮМЕ: Вид Asianopis goalparaensis (Tikader et Malhotra, 1978) comb.n., относящийся к группе видов liukuensis, переописан по свежим экземплярам, собранным в Ассаме, Индия. Даны детальные иллюстрации, карта распространения и наблюдения по биологии вида.

\section{Introduction}

The Asian deinopid genus Asianopis Lin et Li, 2020 was recently erected, with $A$. zhuanghaoyuni $\mathrm{Lin}$ et Li, 2020 as its generotype [Lin et al., 2020]. The genus consists of seven valid species, of which only Asianopis liukuensis (Yin, Grisworld et Yan, 2002) is known from India [WSC, 2020]. Two species were earlier described from India: viz., Deinopis goalparaensis Tikader et Malhotra, 1978, which is currently considered nomen dubium [Caleb, 2019], and D. scrubjunglei Caleb et Mathai, 2014, a junior synonym of $A$. liukuensis [Lin et al., 2020]. The specimens of $D$. goalparaensis collected by Tikader [Tikader, Malhotra,
1978] were from Jamduar, a former part of Goalpara District, Assam. In July 1983, Goalpara was partitioned into Dhubri and Kokrajhar Districts and Jamduar fell under Kokrajhar District. The place is located in the eastern Raimona forest range, being part of the Ripu Reserve Forest under the Manas Biosphere Reserve [Forest Department, 2009]. This place is known for its magnificent scenic landscapes surrounded by Bhutan Hills harbouring diverse flora and fauna.

The genus Asianopis consists of two species groups [Lin et al., 2020]: viz., the liukuensis-group and the zhuanghaoyuni-group, of which the former includes two nominal species - $A$. dumogae (Merian, 1911) and A. liukuensis (Yin, Griswold et Yan, 2002). D. goalparaensis belongs to this group, as it shares the following diagnostic characters thereof: proximally enlarged femora I; pear-shaped carapace; female chelicerae having four pro- and seven retromarignal teeth, with numerous denticles between them; epigyne with an anchor-shaped median plate; distinct copulatory openings; insemination ducts with three turns; and oval spermathecae [Lin et al., 2020].

The present paper is aimed at the redescription of D. goalparaensis on the basis of newly collected material from the same district where the type locality lies. Detailed illustrations, a distributional map and notes on its natural history are provided.

\section{Materials and methods}

Specimens were hand collected during a night survey and photographed using a Sony Cyber-shot DSC-HX90V camera. The specimens were observed and photographed under a Leica EZ4 HD stereomicroscope enabled with a 

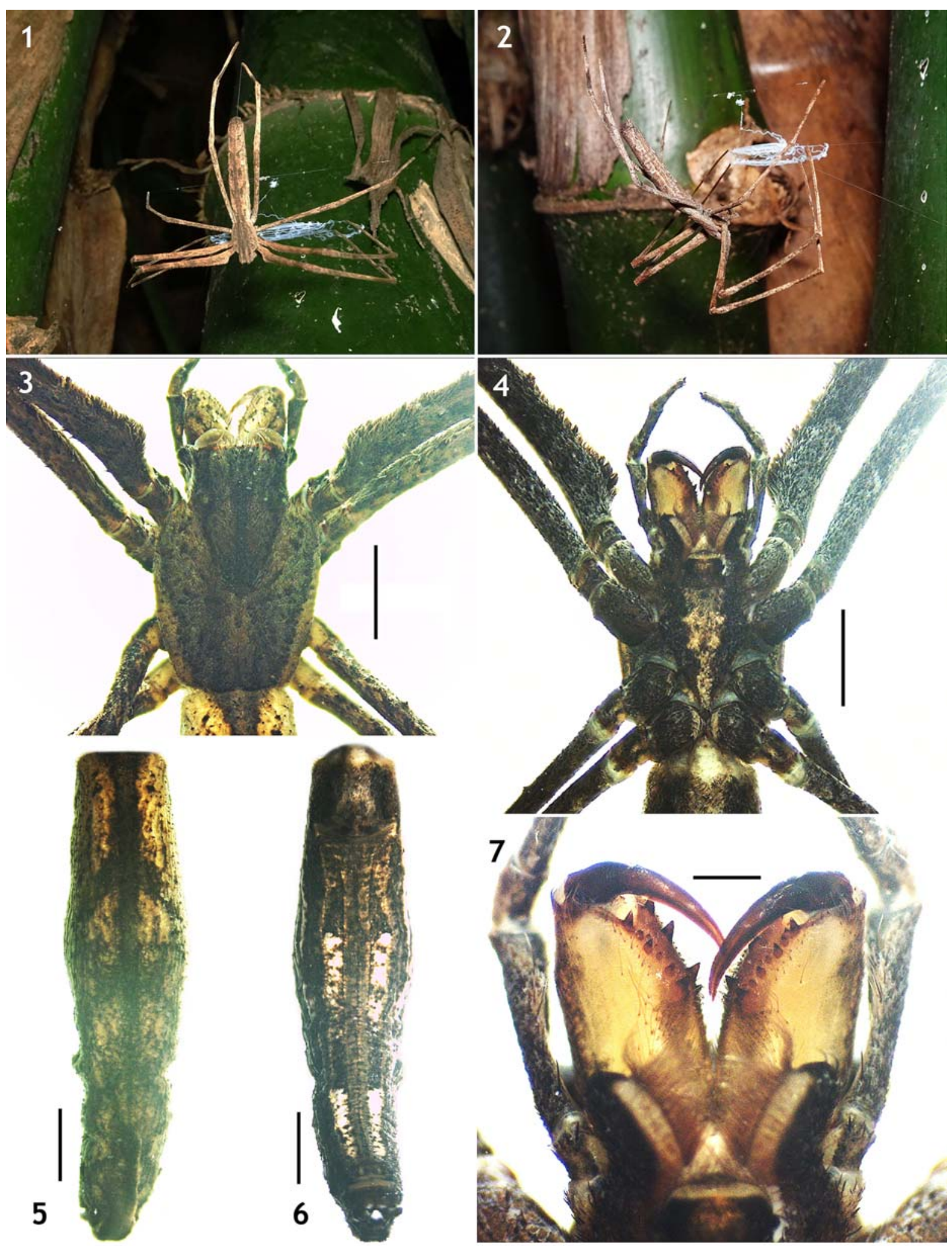

Figs 1-7. Somatic morphology of Asianopis goalparaensis (Tikader et Malhotra, 1978) comb.n., female: 1 - general appearance, dorsal view; 2 - ditto, lateral view; 3 - prosoma, dorsal view; 4 - ditto, ventral view; 5 - abdomen, dorsal view; 6 - ditto, ventral view; 7 - chelicerae, ventral view. Scale bars: (3-6) $2 \mathrm{~mm}$, (7) $0.5 \mathrm{~mm}$.

Рис. 1-7. Соматическая морфология Asianopis goalparaensis (Tikader et Malhotra, 1978) comb.n., самка: 1 - общий вид сверху; 2 - то же, сбоку; 3 - просома, сверху; 4 - то же, снизу; 5 - брюшко, сверху; 6 - то же, снизу; 7 - хелицеры, снизу. Масштаб: (3-6) 2 мм, (7) 0,5 мм. 

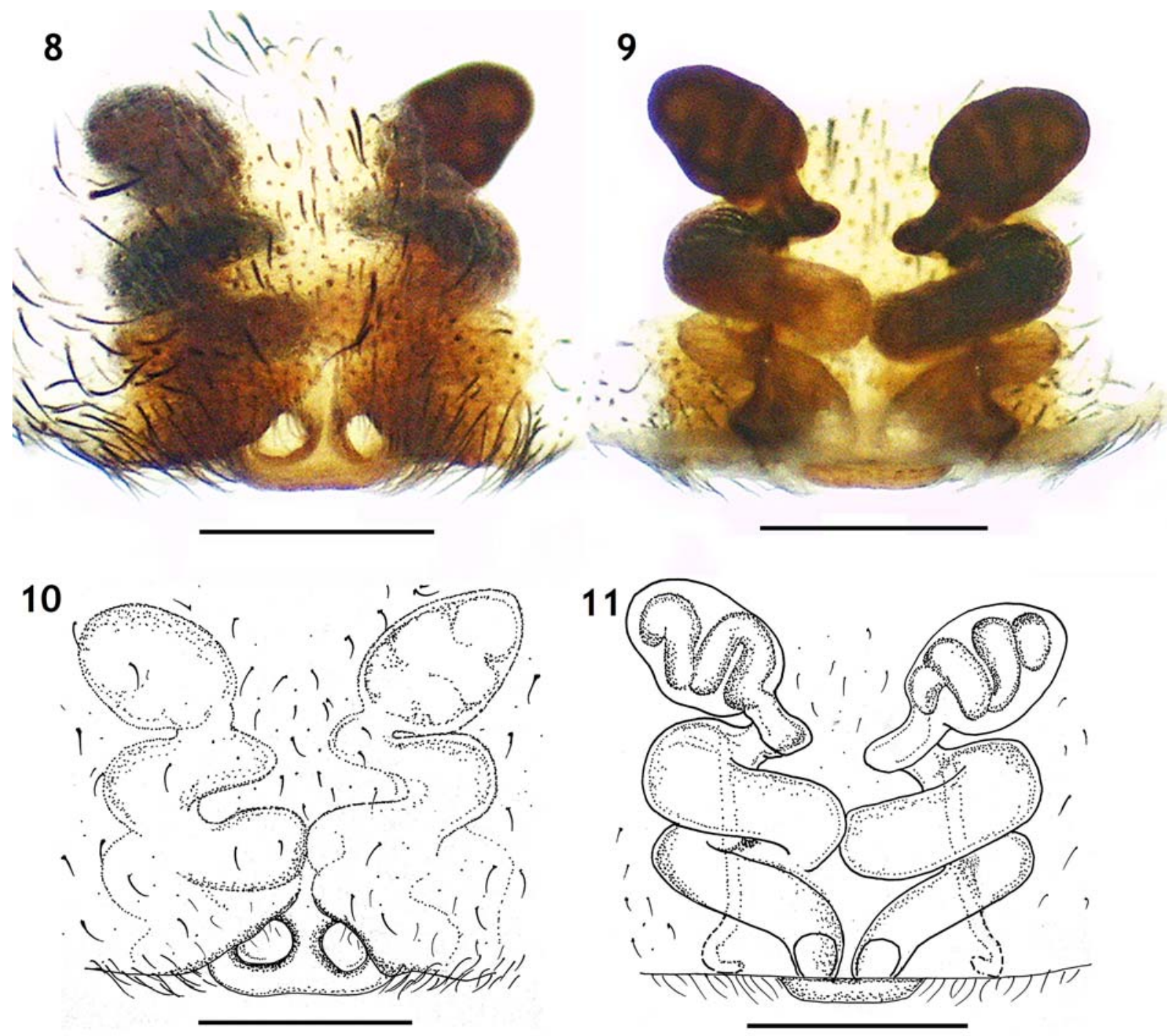

Figs 8-11. Female copulatory organs of Asianopis goalparaensis (Tikader et Malhotra, 1978) comb.n.: 8, 10 - epigyne, ventral view; 9,11 - vulva, dorsal view. Scale bar: $(8-11) 0.5 \mathrm{~mm}$.

Рис. 8-11. Копулятивные органя самки Asianopis goalparaensis (Tikader et Malhotra, 1978) comb.n.: 8, 10 - эпигина, снизу; 9 , 11 - вульва, сверху. Масштаб: (8-11) 0,5 мм.

Leica Application Suite (LAS EZ), version 3.0. Epigyne was dissected and macerated in $10 \% \mathrm{KOH}$ to clear soft tissue. The type locality coordinates were approximated by using Google Earth Pro. All measurements are in millimeters (mm). Specimens are deposited in the National Zoological Collections, Zoological Survey of India (NZC-ZSI), Kolkata.

\section{Taxonomy}

Genus Asianopis Lin et Li, 2020.

Type species: Asianops zhuanghaoyuni Lin et Li, 2020, by the original designation.

DIAGNOSIS. For detailed diagnosis and description see Lin et al. [2020].

COMMENTS. Lin et al. [2020] described three new Asianopis species and transferred four species from Deinopis MacLeay, 1839 to Asianopis. Yet, they did not consider six other Deinopis species known from SE Asia: viz., Deino- pis aruensis Roewer, 1938 (Indonesia), D. fasciculigera Simon, 1909 (Vietnam), D. gubatmakiling Barrion-Dupo et Barrion, 2018 (The Philippines), D. kollari Doleschall, 1859 (Myanmar and Malaysia), D. labangan Barrion-Dupo et Barrion, 2018 (The Philippines) and D. luzonensis BarrionDupo et Barrion, 2018 (The Philippines), which could also belong to Asianopis. Each of these species has at least one of the diagnostic characters supporting its placement in Asianopis. The female chelicerae with numerous denticles between pro- and retromarginal teeth (in D. gubatmakiling, $D$. labangan and D. luzonensis; see figs $1 \mathrm{~B}, 5 \mathrm{C}, 6 \mathrm{~B}$ in BarrionDupo \& Barrion [2018]); the prominent setal fringe over PMEs (in D. kollari, D. gubatmakiling, D. labangan; cf. fig. $7 \mathrm{~b}$ in Doleschall [1859] and figs 1A, 4A-B in Barrion-Dupo \& Barrion [2018] with fig. 2D in Lin et al. [2020], and in D. fasciculigera: "Oculi antici maximi, pilis erectis et obtusis, superne albidis extus fuscis", see Simon [1909: 74]). D. aruensis has insemination ducts making over eight turns [Roewer, 1938: 19b]. 


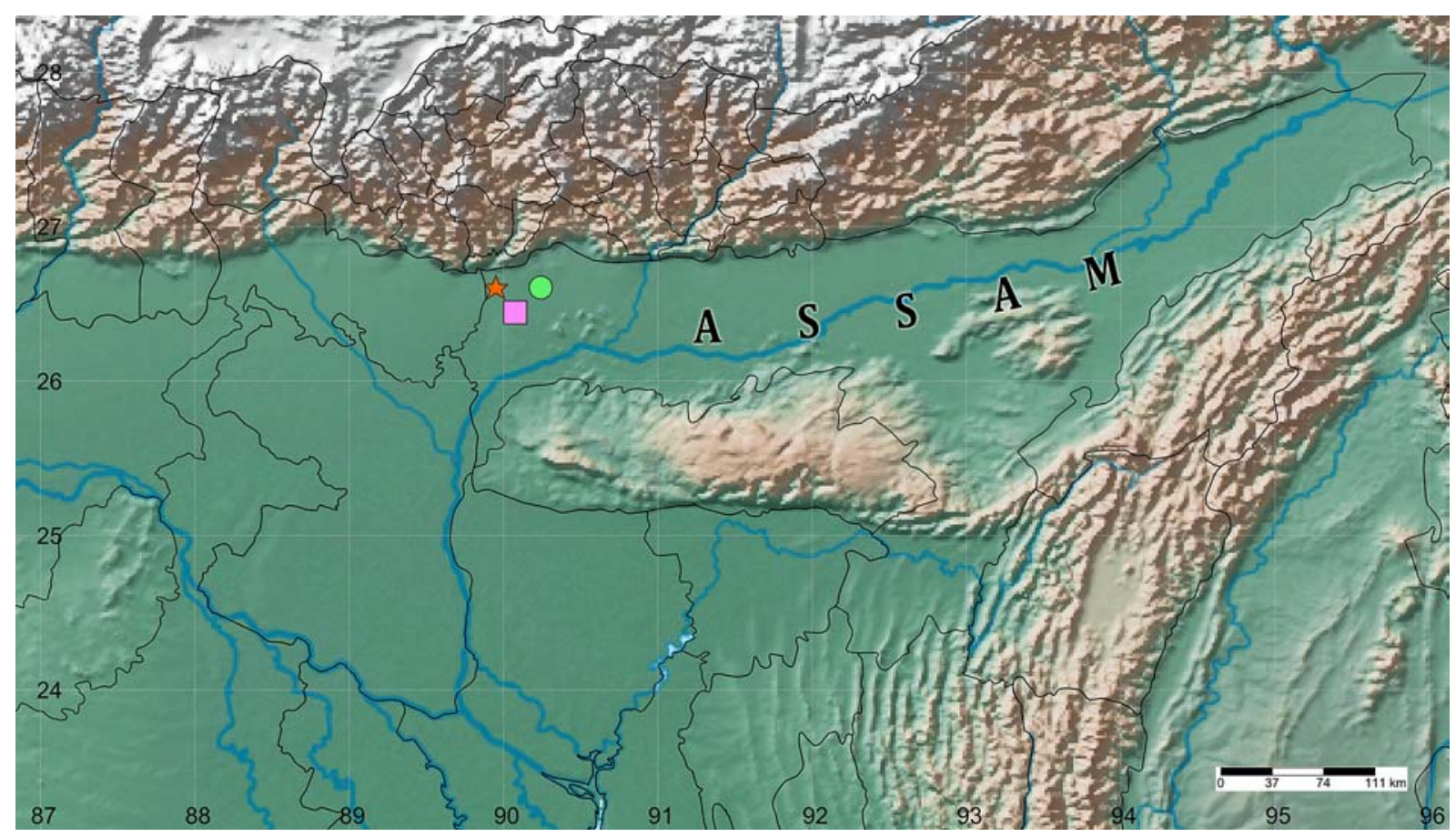

Map. Collecting localities of Asianopis goalparaensis (Tikader et Malhotra, 1978) comb.n. in India. Star represents the type locality (Jamduar), square (Phipsu) and circle (Jharbari).

Карта. Точки сбора Asianopis goalparaensis (Tikader et Malhotra, 1978) comb.n. в Индии. Звезда показывает типовое местообитание (Джамдуар), квадрат (Фипсу) и кружок (Дхарбари).

A. liukuensis is the only Oriental species having a wide distribution from South India to Hainan Island in China. $D$. fasciculigera known from northern Vietnam is likely to be a senior synonym of A. liukuensis, as its type locality lies within the distributional range of the latter species. Such probability was earlier suggested by Logunov [2018]. Nevertheless, $D$. fasciculigera could be represented by a subadult, as it only measures $10-13 \mathrm{~mm}$ in total length [Simon, 1909]. Thus, the assumption that $D$. fasciculigera could be a senior synonym of $A$. liukuensis requires a further justification by reference to the type series of the former species or newly collected topotypes.

Asianopis goalparaensis (Tikader et Malhotra, 1978) comb.n.

Figs 1-11, Map.

Deinopis goalparaensis Tikader et Malhotra, 1978: 157, figs 1-5 (description of a juvenile, not female)

Deinopis goalparaensis: Caleb, 2019: 148, figs 1-11 (nomen dubium).

MATERIAL: INDIA: 19 (NZC-ZSI), Jharbari Forest Range, Assam $\left(26.6052^{\circ} \mathrm{N}, 90.2419^{\circ} \mathrm{E}\right), 74 \mathrm{~m}$ a.s.1., 10.09.2018, P. Basumatary; 1 \% (NZC-ZSI), Phipsu, Assam $\left(26.44384^{\circ} \mathrm{N}, 90.07591^{\circ}\right.$ E), $72 \mathrm{~m}$ a.s.1., 23.09.2018, P. Basumatary.

DIAGNOSIS. In general morphology, A. goalparaensis is similar to $A$. liukuensis from which it can be distinguished by the insemination ducts forming two and a half spirals; the spermathecae directed laterally, opposing each other with a wide V-shaped gap in between (insemination ducts with three spirals and closely placed spermathecae in A. liukuensis: cf. Figs 9, 11 with figs 6, 8 in Lin et al. [2020]).

COMMENTS. The studied specimens were observed and collected from near the type locality of D. goalparaen- sis in Assam, India (see Map). The morphological characters match those of the type specimens (cf. Figs 3-6 with figs 14 in Caleb [2019]), thus leaving no doubt that the studied specimens indeed belong to $D$. goalparaensis.

DESCRIPTION. MALE unknown.

FEMALE. Total length 16.18. Carapace 5.18 long, 3.53 wide; abdomen 11 long, 2.72 wide. Carapace yellowish brown, covered with dense short greyish hairs, with a pale black longitudinal patch medially from the base of posterior median eyes till fovea pointed posteriorly. Short blackish spines on both the lateral sides of thoracic regions; coarse blackish hairs forming a horn-shaped projection, along with small blackish setae over posterior median eyes (Figs 1, 3). Chelicerae yellowish brown, with four pro- and 7-8 retromarginal teeth and many denticles between the pro- and retromarginal teeth. Sternum blackish, with a pale yellow triangular patch medially. Labium and maxillae blackish, with pale yellow margins and tufts of brownish hairs (Figs 4, 7). Legs covered with blackish hairs; femora I-IV with spines retrolaterally, femur I with basal enlargement and tuft of hairs prolaterally, femora I-II blackish distally, patellae I-IV blackish, metatarsi I-IV blackish just above the proximal ends, tip of tarsi I-IV blackish (Figs 2, 4). Abdomen elongated, yellowish brown, with a medial brownish longitudinal patch pointed posteriorly and chevron markings merge with the patch, a pair of slight lateral bumps present in anterior half; ventrally blackish, with two pairs of short pale yellow patches: one at mid-venter and another at posterior end; a broad yellowish brown longitudinal margin runs from epigastric furrow to the cribellum. Spinnerets dark brown (Figs 5,6). Epigyne with anchor-shaped median plate; a pair of rounded copulatory openings surrounded by plumose hairs; spiral insemination ducts make two and a half spirals, their 
anterior portions narrow; spermathecae oval, diverging laterally (Figs 8-11).

NATURAL HISTORY. The species occurs in the mixed shrub vegetation and bamboo patches (Figs 1,2). Specimens were frequently found at a height of about three feet above the ground level, but at some instances a few individuals were found at about eight feet high. It was also observed that the length and width of the net casting web increased as the individuals grew older: i.e., from a small web measuring one centimeter approximately in juveniles to three centimeters in subadults and finally five to six centimeters in gravid females. The web colour is also changed abruptly from pale white in juveniles to milky white in adults.

DISTRIBUTION. India, Assam (Map).

Acknowledgements. Our sincere thanks go to the Additional PCCF \& CHD, Forest, BTC, Kokrajhar, for granting a permission to conduct the study at the Ripu-Chirang Reserve Forest. We greatly acknowledge the Assam State Biodiversity Board for granting the collection permit. We owe our sincere thanks to Dr Kailash Chandra, the Director, Zoological Survey of India, Kolkata, for giving access to the facilities and his support. Our heartfelt thanks also go to Tunu Basumatary, Niren Borgoyary, Pabidash Narzary, Jarang Basumatary and Karma Gayary for aiding with fieldwork. We are indebted to Dr. D.V. Logunov (Manchester, UK) whose suggestions, linguistic and editorial inputs greatly improved the manuscript.

\section{Compliance with ethical standards}

Conflict of Interest: The authors declare that they have no conflict of interest.

Ethical approval: No ethical issues were raised during our research.

\section{References}

Barrion-Dupo A.L.A., Barrion A.T. 2018. Discovery of the family Deinopidae from the Philippines, with descriptions of three new species of Deinopis Macleay, 1839 // Philippine Entomologist. Vol.31. No.1. P.1-23.

Caleb J.T.D. 2019. The Indian net-casting spider name Deinopis goalparaensis Tikader \& Malhotra is a nomen dubium (Araneae: Deinopidae) // Zootaxa. Vol.4668. No.1. P.148-150.

Doleschall L. 1859. Tweede Bijdrage tot de kennis der Arachniden van den Indischen Archipel // Acta Societatis Scientiarum Indica-Neerlandica. Vol.5. S.1-60.

Forest Department, BTC. 2009. Profile on forest and Wildlife, BTC. P.12, 16.

Lin Y.J., Shao L., Hänggi A., Caleb J.T.D., Koh J.K.H., Jäger P. \& Li S.Q. 2020. Asianopis gen. nov., a new genus of the spider family Deinopidae from Asia // ZooKeys. Vol.911. P.67-99.

Logunov D.V. 2018. A new ogre-faced spider species of the genus Deinopis MacLeay, 1839 from Vietnam (Aranei: Deinopidae) // Arthropoda Selecta. Vol.27. No.2. P.139-142.

Roewer C.F. 1938. Résultats scientifiques du Voyage aux indes orientales néerlandaises de la SS. AA. RR. le Prince et la Princesse Leopold de Belgique. Araneae // Mémoires du Musée Royal d'Histoire Naturelle de Belgique. Vol.3. No.19. P.1-94.

Simon E. 1909. Etude sur les arachnides du Tonkin (1re partie) // Bulletin Scientifique de la France et de la Belgique. Vol.42. P.69-147.

Tikader B.K., Malhotra M.S. 1978. A new record of rare spider of the family Dinopidae from India with description of a new species // Proceedings of the Indian Academy of Science. Vol.87. No.6. P.157-159.

WSC 2020. World Spider Catalog. Version 21.0. Natural History Museum Bern, Bern. Available from: http://wsc.nmbe.ch (accessed 6 May 2020).

Yin C.M., Griswold C.E., Yan H.M. 2002. A new ogre-faced spider (Deinopis) from the Gaoligong Mountains, Yunnan, China (Araneae, Deinopidae) // Journal of Arachnology. Vol.30. No.3. P.610-612.

Responsible editor D.V. Logunov 